\title{
History, Hysteria, and Hype: Government Contracting with Faith-Based Social Service Agencies
}

\author{
Edward Queen \\ Center for Ethics, Emory University, GA 30322, USA; equeen@emory.edu; Tel.: +1-404-519-9243 \\ Academic Editor: Robert Wineburg \\ Received: 23 March 2016; Accepted: 20 January 2017; Published: 10 February 2017
}

\begin{abstract}
In light of the adoption of the Charitable Choice Provision of the Welfare Reform Bill and the creation of White House Offices on faith based initiatives this article examines the history of government contracting with faith-based organizations to deliver human and social services with a particular focus on how the U.S. Supreme Court has viewed the legal status of such contracts.
\end{abstract}

Keywords: Charitable Choice; faith-based; church-state; contracting

In 1996 when the Personal Responsibility and Work Opportunity Reconciliation Act (PRWORA) was adopted by Congress and signed into law by the then President Clinton, it contained within it a provision that raised little attention at the time, but has since received immense public focus and even led to the establishment of a White House office. Section 104 of PRWORA of 1996, the so-called "Charitable Choice" provision, has moved from insignificance to importance. Virtually ignored in the leading history of the welfare reform bill, this provision—or more precisely its policy implications and the efforts to adopt similar provisions in federal funding bills-became the centerpiece of much of President George W. Bush's domestic policy, capped off by the creation of the White House Office of Faith-Based and Community Initiatives (now the Office of Faith-Based and Neighborhood Partnerships).

While the departure of the office's first director, John DiIullio, after only seven months in office and the terrorist attacks on the World Trade Towers and the Pentagon on 11 September 2001, removed both the momentum and the focus of the policy, it remained an important part of the Bush administration's domestic agenda and was continued under President Obama. Although the White House Office constricted following DiIullio's announced departure and the administrative exile of many of the most ideological proponents of the policy, the impetus remains. In late January of 1991, President Bush ordered the creation of a Center for Faith-Based and Community Initiatives in five executive departments-Health and Human Services, Housing and Urban Development, Justice, Education, and Labor [1]. In his executive order, the president stated that the purpose of the centers would be "to coordinate department efforts to eliminate regulatory, contracting, and other programmatic obstacles to the participation of faith-based and other community organizations in the provision of social services." [1]. While there was some shift in emphasis under President Barack Obama, including the office's name change, in many ways President Obama extended the work in other directions. This included a program focused on college students, the Interfaith and Community Service Campus Challenge, and, perhaps more importantly, the establishment of the Office of Religion and Global Affairs in the Department of State and the appointment of Shaun Casey as the Special Representative for Religion and Global Affairs.

During the Bush administration, perhaps his most important related appointments was that of Carl Esbeck to the position of director of the faith-based center at the Department of Justice. Mr. Esbeck, on leave from his position as professor of law at the University of Missouri, served as a key advisor to then Senator, and later Attorney General, John Ashcroft in drafting the language for what became the Charitable Choice provision. In his position at the Department of Justice, Mr. Esbeck aggressively 
promoted the view that the Charitable Choice provision and its successor provisions were, in essence, simply changes in procurement rules. These changes, he argued, were designed to allow faith-based human and social service agencies that previously might have been excluded from participating in governmental contracting to enter the system, assuming they had the capacity to do so [2].

The White House Office of Faith-Based and Community Initiatives promoted a similar view. Two of the main goals of the Office, according to its web page, were to:

- Identify and act to remedy statutory, regulatory, and bureaucratic barriers that stand in the way of effective faith-based and community social programs;

- Ensure that, consistent with the law, faith-based programs have equal opportunity to compete for federal funding and other support [3].

The incorporation of the Charitable Choice provision into PRWORA in the Welfare and the creation of the Office of Faith-Based and Community Initiatives into the White House was accompanied by hysteria across the political spectrum, from those who claimed it would solve all the problems of the welfare system to those who viewed it as the beginning of theocracy ${ }^{1}$. This article elides that discussion and instead seeks to place the Charitable Choice provision into a much ignored history, or perhaps histories, namely the way governments in the United States-from local to federal-have used faith-based organizations (FBOs) for the provision and delivery of social and human services and how the courts have interpreted the constitutionality of such contracts in light of the establishment clause ${ }^{2}$.

\section{The History of Government Contracting with Faith-Based Organizations}

A major reason for the poor quality of the public discourse surrounding Charitable Choice and the wider issue of Faith-Based initiatives is that there exists little knowledge of the topic of contracting with FBOs for the delivery of service and a lack of familiarity with the legal and practical issues involved. An additional source of confusion involves the absence of clarity in defining a faith-based organization. While there has been some notable and significant work on clarifying such understandings ${ }^{3}$, for this paper the following issues are core to determining whether an entity ought to be considered a faith-based organization or not:

(1) Does the organization understand its reason for existence or its undertaking activities as motivated or structured by religious beliefs (particularly as articulated in pertinent documents)?; or

(2) Would a reasonable and neutral outside observer describe the organization and its work as being religiously motivated or structured ${ }^{4}$ ?

To a great extent, with some exceptions to be noted, the Federal Government did little contracting - either directly or indirectly-for the provision of human and social services until the 1950s and 1960s. Given the absence of federal involvement, there emerged few challenges based on the United States Constitution. Although state and local governments regularly used religious or

For a discussion of the "success" of faith-based organization in the delivery of such services, see [4].

2 Constitution of the United States, Amendment I. "Congress shall make no law respecting an establishment of religion..." For a general history of establishment clause jurisprudence see the following classic study, although somewhat dated [5]. For a more contemporary discussion see [6].

3 For one of the most successful attempts to bring clarity to defining faith-based organizations see [7]. This article is valuable in helping researchers understand the differences between and among such organizations, the distinctions it draws are less relevant for legal analyses because the categories are bright lines that the courts increasingly are reluctant to observe. See note 4 below.

4 While one might find these characterizations too vague, it is important to recognize that even in judicial decisions there is no clearly drawn line. As the Ninth Circuit stated in Spencer v. World Vision "each case must turn on its own facts. All significant religious and secular characteristics must be weighed to determine whether" an organizations character is religious. Spencer v. World Vision, Inc., 619 F. 3d 1109, 1112. 
faith-based agencies to deliver human and social services, until the U.S. Supreme Court, in its decision in Everson v. Board of Education of Ewing Township ${ }^{5}$, formally declared that the Establishment Clause was incorporated into the rights protected by the Fourteenth Amendment and, thereby, applicable to the States, such state practices did not give rise to federal constitutional questions ${ }^{6}$. Finally, until the second half of the twentieth century the monies expended on these issues were relatively small (again with some very specific exceptions). Only with the growth of the welfare state did the issue of government contracting with religious-based providers of service become an issue of major importance . $^{7}$

Despite the need to be cautious about drawing conclusions from activities undertaken in dramatically different legal and social situations, it remains important to be reminded that such contracting is not a new phenomenon. The federal government, as well as state and local governments, have paid religious organizations to provide much needed social and human services and have occasionally worked closely in such partnerships through the payment of subsidies, coordination of efforts, and government provision of certain advantages to these organizations.

\section{The Beginnings}

A history of such partnerships highlights the fact that many of the boundaries currently taken for granted have not been as immutable or as long-lived as one might suspect ${ }^{8}$. To understand the phenomenon more clearly, we must first look at the history of government contracting for the delivery of human and social services, paying particularly close attention to the partnerships between government and faith-based organizations.

The history of government funding of services provided by private organizations, especially private eleemosynary organizations, is a long one ${ }^{9}$. In reviewing this history in light of the policies of the Reagan administration, Lester Salamon wrote, "Government support of voluntary organizations has roots deep in American history. Well before the American Revolution, for example, colonial governments had established a tradition of assistance to private educational institutions, and the tradition persisted into the nineteenth century" [10,11].

This may first strike one as strange, because few would think that nothing could be clearer than the boundary between the state government and private higher education, especially for schools of higher education established for specific religious purposes. Nearly all would agree that Harvard University holds a preeminent place among the private institutions of higher learning in the United States. Established in 1636 with its primary mission the education of ministers for the Congregational Churches of New England, Harvard's identity as both a private institution and (at least initially) a religious one cannot be denied.

Yet the connection between Harvard University and the state of Massachusetts was both intimate and long-lived. The state of Massachusetts enacted a special tax for the support of the school and paid part of the president's salary. Until after the Civil War, the state legislature also appointed the university's board of directors. In Connecticut, Yale University, which had been established in response to Harvard's perceived theological liberalism, received similar support [12].

5 Everson v. Board of Education of Ewing Township, 330 U.S. 1 (1947).

6 Challenges could have been made on the basis of the state constitutions and most states have religion clauses in their constitutions similar to those in Amendment I of the U.S. Constitution while several have language that is much more strictly separationist.

7 For a discussion of the growth of government contracting with nonprofit organizations see [8].

8 For lawyers' love of boundaries, see [9].

9 This paper uses the phrases, charitable organizations, charities, nonprofits, and similar terms interchangeably, largely ignoring what may be certain specific differences that may be of interest to specialist scholars. Part of the reason for this is to guarantee some variety in the writing, but often the sources themselves use different terms to describe the same sets of organizations. Roughly speaking, all of the terms used can be understood to include any organization that could be recognized as a 501(c)(3) tax-exempt, tax-deductible organization under the Internal Revenue Code. The paper also uses the terms, religious organization, faith-based organization, faith-based service provider, religious charities, and so forth as synonyms. All of these terms are to be understood to include any organization described in the preceding paragraph that views religion and religious beliefs to underlie its reason for existence. 
Colleges and universities were not the only places where governments provided support to private, often faith-based, organizations that delivered services. State governments provided financial support to private hospitals, as well as orphanages and poor houses, many of which were religious in nature. For example, in 1806 the New York Orphan Asylum, a decidedly Protestant organization, established an orphanage, which, by decade's end, received state monies to support over 200 orphans [13].

With the growth of major urban areas in the late nineteenth century, public expenditure for services increased to such an extent that by the "last quarter of the century, subsidies became the prevailing method for financing most voluntary institutions." [14]. In the medical field, an 1889 survey of seventeen major hospitals revealed that $12 \%-13 \%$ of their income came from government sources and a 1904 Census Bureau survey estimated that governments provided eight percent of all hospital income nationwide, a figure exceeded in many states [10].

Given that the overwhelming number of private hospitals at that time had been established under the auspices of religious organizations a large portion of this money went to hospitals founded on religious principles. The first Supreme Court case addressing the issue of government contracting with a religiously affiliated provider involved a hospital founded and operated by a religious order, a fact that gave the Supreme Court no pause in allowing the federal subsidies ${ }^{10}$.

Medical treatment was not the only or even the primary place where state and local governments contracted with private non-profit organizations to provide services. The area of poor relief in general was a major locale where government monies were given to private organizations for the delivery of services.

In New York City, an 1880s study of 200 private orphanages found that these organizations received twice as much of their funding from government support as they received from legacies, donations, and private contributions ([10], p. 101). For all social services in that city, the amount the local government paid to reimburse private benevolent institutions for the care of prisoners and paupers grew faster than did total city expenditures for those purposes.

New York City's expenditures for social services increased from less than $\$ 10,000$ in 1850 (the equivalent of nearly $\$ 300,000$ in 2016) to over $\$ 3$ million (over $\$ 82$ million in 2016) by 1898 . This means that between 1850 and 1898 city expenditures for the care of the poor, indigent, and prisoners increased from a mere $2 \%$ of the city's budget to $57 \%$ of the budget. ([10], p. 101; [15]). While impossible to separate out what percentage of these monies actually went to religious organizations, an examination of the funding of orphanages can be illustrative. Most orphanages during that time were established along religious lines and served orphans of a particular faith. In fact, they were subsidized by New York and other cities for doing exactly that. That both the state government and others recognized this fact is illustrated by the 1863 act of the New York legislature to charter the Roman Catholic Protectory to receive truant, vagrant, and delinquent children whose parents or guardians had requested the courts to commit them to a Catholic establishment rather than to the House of Refuge or other predominantly Protestant institutions [16].

In the provision of poor relief more generally, we know that the Salvation Army was a recipient of city funds, as were many other religious providers in New York [17]. The New York Association for Improving the Condition of the Poor (a predominantly Protestant organization), the Society of St. Vincent De Paul, and the United Hebrew Charities were among the private charities that received monies derived from New York City's excise taxes on alcohol and tobacco ([16], p. 184). By the beginning of the twentieth century, the use of private non-profit organizations for the provision of services to the orphaned, the sick, and the destitute was widespread throughout the United States. A 1901 federal survey of governmental subsidies of private charities found that "except possibly two territories and four western states, there is probably not a state in the union where some aid is not given

10 Bradfield v. Roberts 175 U.S. 291 (1899). 
[to religious organizations] either by state or by counties and cities." ([10], p. 101; [15], p. 360). While the Constitutions of some states prevented government monies from going to religious organizations, cities still found them appropriate providers, as did many other states ${ }^{11}$.

Even in states where the constitution seemingly forbade the payment of government monies to "sectarian" institutions, this limitation often was evaded through numerous subterfuges. Many ostensibly non-sectarian institutions were completely Protestant in ethos and practice. Catholics and Jews, in order to protect their religious rights, felt compelled to compete equally for government monies in order to prevent their co-religionists from being either under-served or from falling into the clutches of an alien religion ${ }^{12}$. Additionally, states often found ways around such limitations. A 1917 decision by the Illinois State Supreme Court rejected the claim that county payments to a sectarian institution for care of the poor violated that state's constitutional ban on aid to such organizations. The court reasoned that if the county paid the institution less than the actual cost of care, this could hardly be called aid to a sectarian organization, and so would not be a violation of the constitution [19].

Amos Warner, in his influential and oft reprinted study of private benevolent institutions in the late-nineteenth century United States, actually attributed much of the growth of governmental subsidies to private eleemosynary institutions to the influence of religious institutions. He claimed that, "The growth and persistence of the subsidy system, particularly in caring for dependent children, is closely connected with the desire of different churches to control their education in morals and religion." ([18], p. 407). Warner pointed out that $45 \%$ of all orphanages and children's homes in the United States were under express religious control and that "a considerable percentage of those nominally non-sectarian are, in fact, strongly under sectarian influence." ([18], p. 407). He noted that, "Many institutions having no trace of sectarianism in charter, constitution, or by-laws are yet administered in the interests of a sect," and that while the willingness of an institution to admit individuals of all denominations often was used to advertise its non-sectarian nature, he noted that such a fact was "frequently less an evidence of non-sectarianism than of a tendency to make proselytes." ([18], p. 408) ${ }^{13}$.

Although the above demonstrates that state and local governments did not necessarily shy away from working with private benevolent organizations, including religious organizations, in providing care for those in need, it tells us little about the role of the federal government. To some extent this does not surprise, because, as noted previously, the federal government's role in such provision was minimal until the advent of the New Deal. While the federal government's relations with the Native American peoples might be informative in this regard, the distinctive context of that work and the

11 Particularly following the Civil War numerous states adopted what were popularly known as Blaine Amendments. They were named after James G. Blaine a U.S. representative from the Maine who introduced a U.S. Constitutional amendment to prohibit the use of governmental monies for "shall ever be under the control of any religious sect; nor shall any money so raised or lands so devoted be divided between religious sects or denominations." While the amendment passed overwhelmingly in the U.S. House of Representatives, it fell four votes short in the U.S. Senate. This led to the amendment of many state constitutions to adopt some variation of the above language. By the 1970 s 38 of the 50 states had some version of the amendment in their state constitutions. Since that time, however, there have been concerted attempts to repeal the amendments, beginning with Louisiana in 1974.

12 "In States where a constitutional limitation forbids the voting of public money to 'sectarian' institutions, members of the Protestant denominations often seek to have this clause so interpreted as to exclude the institutions offered by the Roman Catholic orders, while charitable enterprises in which they are themselves interested are nominally unsectarian. The Catholics not infrequently try to evade the constitution limitation by disingenuous subterfuges; and the Protestants...encourage such a course by their own eagerness to secure public money for the private institutions in which they are themselves interested" [18].

13 This point needs to be taken most seriously. In the nineteenth century "sectarian" often was used in a very specific sense to denote religions or denominations and their affiliated organizations that solely were operated for their members. This definition or understanding excluded many organizations that a neutral observer would have considered religious. These organizations, such as the New York Orphan Asylum mentioned above and seemingly non-sectarian were established by Protestant Christians and the ethos and training were decidedly Protestant in ethos. Since they were not denominated as Protestant, were comprised of Protestants of various denominations, and did not limit their services (although did limit their hiring) to Protestants, they claimed to be "non-sectarian." Catholic and Jews found such claims unconvincing. 
unique Constitutional issues involved make such an examination too sui generis to be useful ${ }^{14}$. In one location, however-Washington, D.C.- - the role of the federal government in funding social services was central, since Congress itself functioned as D.C.'s city council.

\section{Congress, Washington, D.C. and Bradfield v. Roberts}

By the late nineteenth century, the provision of poor relief and indigent services in Washington, D.C. reflected that of most other cities in the northeast. An examination of the city's budget for that period found that not only was Congress, which functioned as D.C.'s city council and established its budget, willing to compensate private charities for the services they provided to the District's poor, but that Congress also provided funds to pay for the construction of the buildings used by these organizations.

By the last decade of the nineteenth century about half the public funds allocated by Congress for poor aid within the District of Columbia went to private charities and these charities also absorbed over $60 \%$ of the funds granted for construction of charitable facilities between 1880 and 1892 ([18], p. 337). These institutions included numerous private charitable institutions "avowedly under sectarian management" ([18], p. 401).

This funding led to the first case (and the only one before the 1980s) heard by the United States Supreme Court regarding the constitutionality of providing federal funds to religious social service providers ${ }^{15}$. The suit, Bradfield $v$. Roberts, challenged Congress's appropriation of federal funds for capital improvements for a church-related hospital in the District of Columbia.

Although decided on fairly narrow grounds, the facts surrounding the case are illuminating. In April of 1864 Congress incorporated Providence Hospital in Washington, D.C. The act of incorporation gave the corporation "full power and all rights of opening and keeping a hospital in the city of Washington for the care of such sick and invalid persons as may place themselves under treatment and care of said corporation"16. The Sisters of Charity of Emmitsburg, Maryland held the title to Providence Hospital. Its founding directors were all members of that order and held their positions as a self-perpetuating board of directors.

Three years later in April 1867, Congress appropriated $\$ 30,000$ (\$462,463 in 2016 dollars) for the construction of two isolation buildings to be operated as part of local hospitals, one of which was to be located at Providence Hospital. The appropriation was subject to two-thirds of the isolation building being for "the use of such poor patients as shall be sent there by the Commissioners of the District...." In return the hospitals were to be paid $\$ 250$ per annum (pro rata) ( $\$ 3,854$ in 2016 dollars) "for such a time as such patient may be in the hospital, subject to Annual Appropriations of Congress"17.

Complainant objected to the appropriation on the grounds that the contract between the hospital and the federal government was "unauthorized by law" and:

involved a principle and a precedent for the appropriation of the funds of the United States for the use and support of religious societies, contrary to the article of the Constitution which declares that Congress shall make no law respecting a religious establishment, and also a precedent for giving to religious societies a legal agency in carrying into effect a public and civil duty which would, if once established, speedily obliterate the essential distinction between civil and religious functions ${ }^{18}$.

The opinion, issued by Mr. Justice Peckham, did not even reach the facts alleged. The Court looked at the act of incorporation and found it to be an appropriate legal document creating a private

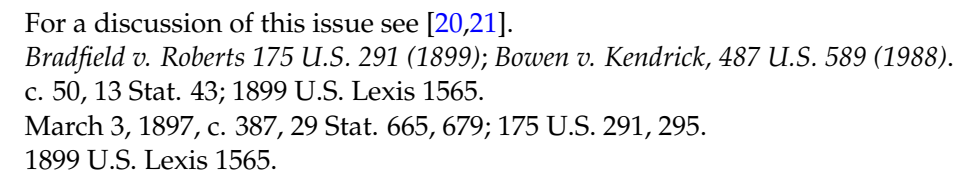


corporation. "[T]he fact that its members...are members of a...sisterhood of the Roman Catholic Church, and the further fact that the hospital is conducted under the auspices of said church, are wholly immaterial..."19

He continued:

That the influence of any particular church may be powerful over the members of a non-sectarian and secular corporation, incorporated for a certain defined purpose and with clearly stated powers, is surely not sufficient to convert such a corporation into a religious or sectarian body. That fact does not alter the legal character of the corporation... ${ }^{20}$

For the Court, the legal status of the corporation was determinative. Congress had the right and power to charter such a corporation, the corporation had not violated the charter in its operation, and Congress had the right to make the appropriations it made and to authorize the Commissioners of the District to enter into the service contract. The case was dismissed for failure to state a cause of action.

The case is almost as interesting for what was not decided as for what was. The Court left aside the question of whether such appropriations would be valid if an organization were, by its charter, an explicitly religious organization. Even if such an appropriation were invalid, the Court said, such is not the case here. One simply has a private corporation, albeit perhaps run by a religious order and operating under the patronage of a denomination, whose operations and management are governed by the document of incorporation and the laws of the land.

At a minimum, what the court allowed in the case was the use of federal funds by organizations designed to provide legitimate secular health services. Who provided that service and from what motivation and impetus was and remained irrelevant.

In Bradfield we see clearly that by the end of the nineteenth century, even in an arena solely under federal jurisdiction and subject to Constitutional limitations, there had developed a formal process by which governments, including the federal government, worked with religious organizations to provide much needed human and social services. Such a formal process as contracting for services was not the only way that the national government worked with religious organizations in the provision of services, however. With the establishment of the Sanitary Commission during the Civil War (as well as the competing commissions organized upon more explicit sectarian lines), there developed strong relationships between the national government and religious organizations in the delivery of a wide variety of services.

\section{The Civil War and Its Aftermath}

The Civil War brought about a major expansion in the power and reach of the national government in the United States. It saw not only the creation of a massive national army and expansion of the navy, but also huge contracts for war materiel as well as the introduction of the income tax. All greatly increased the power of the national government.

During the war, maintaining the health and morale of the troops presented a major challenge to its successful prosecution. Disease, stress, and loneliness all took their toll with disease far outstripping the battlefield as a major source of casualties. To address these problems, many organizations, including religious denominations, undertook numerous activities to aid the soldiers of both armies. While these undertakings did not primarily, or even necessarily, involve the expenditure of government funds to pay for the delivery of services by a faith-based organization, they readily involved a working relationship, often involving government efforts to accommodate or facilitate the work of the religious organizations, work which served military needs and, often, governmental policy. 
While these organizations undertook a wide variety of activities, three predominated. These were medical and nursing care; the maintenance of morals, morale, and sanitation; and services provided to the freedmen. In all of these activities, expressly religious organizations and organizations with a marked religious component were active. Even the United States Sanitary Commission, which, despite its name, was a private entity and nominally non-sectarian, had a prominent Unitarian minister, the Reverend Henry W. Bellows, as its chairman and formal representation from a variety of religious leaders on its board.

In the provision of nursing volunteers, perhaps the most important and, for many the most memorable, were women Roman Catholic religious. Of the estimated 3200 women who served as volunteer nurses during the war, at least 600 were Roman Catholic nuns. The latter, although looked upon with suspicion by some reformers such as Dorothea Dix, were widely admired by the soldiers and the medical corps ([16], p. 73) ${ }^{21}$.

In the provision of services to maintain the morals and morale of the soldiers, religious organizations often were in the forefront. The United States Christian Commission, whose members and activities often found themselves at odds with the Sanitary Commission, distributed religious tracts and Bibles to soldiers, conducted religious services, and undertook what today we would call counseling. It also took an active role in collecting and distributing medical supplies, clothing, food, and other items of personal need among the soldiers. Additionally, like so many volunteers in the war zone, its members, often clergy on leave from their pulpits, served as nurses and orderlies in the hospitals ([16], p. 76). Supported by the YMCA, numerous industrialists, and individual congregations, particularly those of an evangelical bent, the Christian Commission received access to the battlefields and to the military camps and hospitals in undertaking its work.

Organized in November of 1861 during a meeting of YMCA representatives, the Christian Commission's mission was to promote "the spiritual good of the soldiers in the army, and incidentally their intellectual improvement and social and physical comfort." ([16], p. 57). Its General Secretary, the Methodist minister William Boardman, declared it to be the first agency ever to minister both to soldiers' physical and spiritual needs and was particularly well-placed to do so ([16], p. 57).

Its board members included four bishops (two Methodists and two Episcopalians). One of the Methodist bishops, Matthew Simpson — reported to be President Lincoln's favorite preacher-was a close personal friend of both Secretary of War Edwin Stanton and Treasury Secretary Salmon P. Chase. Another commissioner, the Reverend Herman Dyer, had been a college-mate of Secretary Stanton. The Speaker of the House, Schuyler Colfax, also served on the Commission's board. The Christian Commission's annual meetings were held in the hall of the House of Representatives and attended by the President, the Chief Justice, various cabinet secretaries, Senators and Representatives, and senior members of the Army and Navy ([16], p. 58).

In the field, the Christian Commission had ready access to the troops, both in camp and in the hospitals. In the camps, the Christian Commission delivered food, clothing, and wholesome reading materials. Many of the Christian Commission's members saw the physical aid and support to individuals as the means of demonstrating the essence of true Christianity. Soldiers, one field member wrote,

could not oppose a Christianity that manifested such concern for their bodily comfort. Farina, oranges, lemons, onions, pickles, comfort-bags, shirts, towels given and distributed in the name of Jesus, though designed for the body, gave strength to the soul. To the quickened senses of a wounded soldier parched with fever, far from home and friends,

21 The elaborate habits of some of the religious orders gave rise to stories of soldiers awakening from unconsciousness and upon seeing a woman with a headpiece that looked like wings first believed he was being tended by an angel and on his way to heaven. Undoubtedly he would have been quickly disabused of this perception by both viewing and hearing the ongoings in the hospital ward. 
an onion was a stronger argument for the religion which bestowed it than the subtle reasoning of Renan, and a pickle sharper than the keenest logic of Colenso! [22]

In the field hospitals, the Christian Commission members served as nurses, aides, and orderlies. They provided bandages and other medical supplies along with food and comfort. To accomplish such tasks they required access to the troops' encampments and support from the military and the federal government. The result was a working partnership between the Christian Commission and the federal government. The Christian Commission provided goods and services beyond those provided by the military and in support of it. In return the military gave the Christian Commission access to the troops and assistance in logistics, security, and transportation. While the government provided no reimbursement to the Christian Commission, or for those of any of the other numerous soldiers' aid societies whether religious or secular, the military and the government did provide many other types of aid and a quasi-formal recognition. As the war progressed, these partnerships expanded to include assistance to the refugees it created and to support of the freedmen both during and after the war.

The numbers of refugees, contrabands (enslaved persons liberated during the Union advance), and, later, freedmen presented the Union Army and the federal government with numerous challenges. The responsibility to care for these individuals had devolved upon them and they had to find ways to do so. A wide variety of methods were employed. (General Ben Butler, the military governor of New Orleans, hired the unemployed to clean the city streets for example.) The most common method of dealing with these groups was indirect, through reliance upon private associations, mostly religious.

In no area was this more expansive than in the provision of aid to the freedmen. This work began in September 1861 when the American Missionary Society sent a group to work with freed slaves housed near Fort Monroe in South Carolina. It expanded greatly the following year when General Sherman issued an official request for aid to the abandoned and refugee slaves he was protecting at Port Royal, South Carolina. This work continued through the war and with its end became formalized with the creation of the Freedmen's Bureau under the direction of Major General Oliver Otis Howard. A man of staunch piety and referred to as the "Christian Soldier", Howard was committed to educating and aiding the recently freed slaves. A circular issued over his name in 1865 (although drafted by Lyman Abott his assistant and a minister) stated that the Bureau's policy would be to work with private organizations. "The utmost facility will be afforded to benevolent and religious organizations in the maintenance of good schools for refugees and freedmen until a system of free schools can be supported by recognized local governments" ([16], p. 126).

To achieve this end, the Bureau was to cooperate with,

private benevolent associations of citizens to aid the freedmen, and with agents and teachers, duly accredited and appointed by them...hire or provide by lease buildings for purposes of education whenever such associations shall, without cost to the government, provide suitable teachers and means of instruction and...furnish such protection as may be required for safe conduct of such schools ([16], p. 128).

In practice, the Bureau expanded its mandate significantly. Typically, after an association began constructing a school building, the Bureau would then provide the money necessary to complete it, under the auspices of repairs. After the building was complete, the Bureau would then lease the building from the association on the basis of $\$ 10.00$ (\$258.00 in 2016 dollars) per month paid for each teacher instructing at least thirty students. The result was that the Bureau effectively subsidized the agencies in hiring and supporting teachers by renting from them buildings the Bureau effectively had paid for. In this way the Bureau paid nearly $\$ 6$ million (equivalent to over $\$ 84$ million today) to private benevolent organizations, mostly the American Missionary Association (AMA) and the American Freedmen's Union Commission (AFUC), for educational work among the freedmen.

Both of those organizations had express religious commitments. The AMA demanded a fervent piety of its teachers and felt that it would be "suicidal to subject our missionaries and teachers (both in one) to any body of men not of a religious character; and we cannot separate the educational from 
the religious element" ([16], pp. 129, 133). While less expressly sectarian, the AFUC required that its teachers demonstrate a genuine spirit of love for God and man and, like the AMA, refused to hire Roman Catholics ([16], pp. 129, 133).

In addition to providing funds and access to camps and military areas where the freedmen were held, the military also provided security for these schools in order to protect the teachers and administrators from the hostile and often marauding locals. The sheer size and expanse of this work set the stage for the use of religious organizations to provided services the government desires.

The Spanish-American War and World War I saw similar partnerships between faith-based organizations and the U.S. military in the provision of support services, including medical care to soldiers, sailors, and marines. During both wars the YMCA, and, during Word War I, the newly created organizations such as the National Catholic War Conference and the National Jewish Welfare Board provided religious, social, and recreational services to the troops, and were highly visible in the conflict zones. Just as in the Civil War these organizations were aided in their access to and work with the troops, and were provided with assistance in logistics and given access to the highest level of governmental and military authorities.

While the long-term consequences of these organizations would be highly important-the National Catholic Welfare Board would, post-war, become the National Catholic Welfare Board and eventually, through several name changes, today's United States Conference of Catholic Bishops-the short-lived nature of both wars did not result in major changes in the historic relationship between religious organizations and the federal governments, with one possible exception. World War I saw the emergence of formal organizations working with the federal government that extended beyond the Protestant majority. This shift would have notable consequences down the road.

\section{The Development of the Welfare State}

The depression of 1929 saw economic events overwhelming the social service delivery system in all sectors of American society. The ability of state and local governments, as well as private nonprofit organizations, to address the immense need proved woefully inadequate. Attempts by President Herbert Hoover to call upon the voluntary spirit of Americans to provide help to those in need failed amidst the wide-scale economic meltdown. Similar efforts by President Franklin Roosevelt to establish a coherent public-private partnership to revive the American economy, collapsed amidst court decisions and the lack of private monies.

The result led to a major expansion in the level of services and activities directly funded and provided by the federal government through President Roosevelt's New Deal policies. Although the New Deal shifted the traditional way of delivering services, with the federal government preferring to deliver them through local governmental agencies instead of private organizations, the expansion of perceived governmental responsibility led, after the war, to a massive expansion of federal funds in supplying various social needs and services, from health-care to education.

The 1950s and 1960s firmly established and entrenched the current patterns of governmental funding. All levels of government in the United States-local, state, and federal—-to greater or lesser degrees, pay for the delivery of social service by nonprofits through the use of four forms of support.

These are:

(1) Purchase-of-service contracts, in which the government contracts with an organization to provide a specific service for which the organization receives funds in a lump sum;

(2) Fees-for-services, in which government acts as the payee for the delivery of particular services whether it be health care, job training, etc.;

(3) Direct support through grants, in-kind contributions, low-interest loans or loan guarantees, including construction grants to hospitals under the Hill-Burton act, commodity distribution to homeless shelters and food pantries; and 
(4) Indirect support through grants or vouchers to individuals who then "purchase" services-education, drug-treatment, or housing to name a few options-from approved providers.

This expansion of governmental support, especially federal support, for many services led to conflicts within many religious organizations. The Southern Baptist Convention opposed governmental support to its institutions and many of the various state conventions found themselves facing being forced to allow hospitals and colleges to become independent of state convention control as the leaders of those institutions desired to participate in the growing governmental largesse. Baylor Medical Center and Wake Forest University were among those Southern Baptist institutions that spun themselves off as independent institutions in order to receive federal dollars [23].

The President Lyndon Johnson's War on Poverty and the social policies of President Richard Nixon's administration made even greater use of private non-profits for the delivery of governmental-funded social services. Using non-profits served the goals of both political liberals and political conservatives. It got services to those in need without creating an even larger federal (or state) bureaucracy.

One result was a massive increase in the use of private non-profit service providers. While, as we have demonstrated above, this was nothing new, the sheer growth of federal funding for these services produced a change in kind, not only in degree. The growth of this "contracting regime"-to use the phrase devised by Steven Rathgeb Smith and Michael Lipsky—was so immense that by the mid 1970s the leading non-profit providers of human and social services received major percentages of their support through some form of governmental funding [8]. By the beginning of the Reagan administration " $40 \%$ of the funds spent by federal, state, and local governments in the United States for...human service activities" went to nonprofit organizations [24].

Unsurprisingly, a large percentage of these dollars went to religious social service providers. The magnitude of this can be seen by the fact that by the close of the 20th century the seven largest religious social service agencies were serving over 60 million people annually ${ }^{22}$. For many of these organizations governmental monies dwarf all other sources of funding. In 2015, 62\% of Catholic Charities USA's funding came from government sources and Lutheran Social Services of America received over $45 \%$ of its support from government funding. Even organizations that, for religious or structural reasons, are cautious about accepting governmental monies still received significant amounts from the government. These include World Vision 19.5\%, Habitat for Humanity, $9.8 \%$ and the Salvation Army 8.4\% [26] $]^{23}$.

While several studies demonstrate the near-universal fact that religious social-service providers of every size receive significant amounts of governmental monies one example is illustrative. Stephen Monsma in examining government funding of nonprofit agencies found that of 137 child service agencies that identified themselves as religious, $51 \%$ reported receiving over $40 \%$ of their income from public funds and only $18 \%$ reported taking no governmental monies at all [27]. While the amounts today may be larger, the use of religious organizations to deliver social services is nothing new and is consistent with the long-standing American pattern, but what have the courts had to say about it?

\section{The Supreme Court and the Establishment Clause}

As suggested in the discussion of the Bradfield case, the delivery of governmental monies to faith-based organizations by governments in order to deliver human and social services potentially

22 This amount, based on self-reporting by the Salvation Army, Catholic Charities USA, the Evangelical Lutheran Church of American, and Lutheran Church-Missouri Synod, the YMCA, the YWCA, and the International Union of Gospel Missions, is reported in [25].

23 Since Lutheran Services of America also includes a large number of hospitals a significant proportion of its overall funding comes from fees for service. These amounts were not included in the percentages. Since this list only focuses on the largest charities many smaller agencies with significant governmental funding are not included here. 
implicates the establishment clause of the First Amendment to the Constitution. One challenge in clarifying the legal issues is that much of the jurisprudence is embedded in cases dealing with schools, hospitals, and employment. Determining both the current state of establishment clause jurisprudence and its direction for government contracting with faith-based organizations often requires one to look far afield ${ }^{24}$.

For example, the activities of a religious service provider in hiring only members of its own faith, while perfectly constitutional and statutorily legal, could become invalid if a court were to determine that the religious organization's acceptance of state funds made it "state-actor." As such, it would be forbidden to discriminate under the religion clauses of the First Amendment, or the Court might simply conclude that such religious discrimination is forbidden in instances where governmental funds are directly involved.

It is unlikely that the Court would make a sweeping generalization that turned all recipients of governmental monies into state actors. There are numerous related, narrower questions that courts have to address when governmental monies are placed in the hands of faith-based organizations to deliver human and social services.

An analysis of legal issues surrounding governmental funding of faith-based human social service agencies begins with the religion clauses of the First Amendment to the United States Constitution. This amendment states that, "Congress shall make no law respecting an establishment of religion, or prohibiting the free exercise thereof..." ${ }^{25}$. Although originally applying only to actions by the federal government, as were the entire first ten amendments, both religion clauses have been interpreted by the Supreme Court as incorporated into those rights protected against infringement by the states under the due process clause of the Fourteenth Amendment. Although the Court expressly made this statement in Murdock v. Pennsylvania ${ }^{26}$, the Supreme Court's decision in Everson v. Board of Education ${ }^{27}$ is generally considered the case that formally incorporated the establishment clause into the due process clause of the Fourteenth Amendment, just as Cantwell v. Connecticut expressly incorporated free exercise clause into the Fourteenth Amendment ${ }^{28}$.

While neither of these clauses, particularly free exercise, has been viewed as absolute ${ }^{29}$, both traditionally have been given broad interpretations by the Supreme Court ${ }^{30}$. The breadth of the protections provided to religious practice often appeared broader than it was since many of the leading Supreme Court cases seemingly decided on "free exercise" grounds actually were decided on other Constitutional principles, including free speech and the rights of parents to raise their children ${ }^{31}$.

24 The remainder of this article focuses solely on establishment clause cases. It does not address the current status of "free exercise" cases that have emerged since the Supreme Court's decisions in Employment Division, Department of Human Resources of Oregon v. Smith, 494 U.S. 872 (1990), Church of the Lukumi Babalu Aye, Inc. v. Hialeah, 508 U.S. 520 (1993), City of Boerne v. Flores, 521 U.S. 507 (1997). It also does not address issues raised by the Religious Freedom Restoration Act (1993) 42 U.S.C. ch. 21B or the Religious Land Use and Institutionalized Persons Act (2000) 42 U.S.C. ch. 21C. These both have potential implications for government contracting, however, depending on the legal implications of Burwell v. Hobby Lobby, 573 U.S._(2014). Here it is important to note that the Supreme Court's decision in the Hobby Lobby case was decided on a statutory interpretation of the Religious Freedom Restoration Act, not on a Constitutional basis.

25 United States Constitution. Amendment I.

26 Murdock v. Pennsylvania, 319 U.S. 105 (1943) at 108.

27 Everson v. Board of Education, 330 U.S. 1 (1947).

28 Cantwell v. Connecticut, 330 U.S. 1 (1947).

29 For a stinging (and mostly wrong-headed) view of this see, [28].

30 There have been a few decisions that some may read as glaring exceptions to this. Many would point to the Mormon polygamy decisions as most representative. Reynolds v. United States, 98 U.S. 145 (1879). The predominant view that such deference was the norm lay behind the collective shock that greeted the Court's decision in Smith v. Oregon where, in terms of neutrally valid laws at least, Justice Scalia stated expressly that such deference not only was not the law, it was not even the norm. "We have never held that an individual's religious beliefs excuse him from compliance with an otherwise valid law prohibiting conduct that the State is free to regulate." Employment Division v. Smith, 484 U.S. 872 (1990), at 878-79.

31 Pierce v. Society of Sisters 268 U.S. 510 (1925), Wisconsin v. Yoder, 406 U.S. 205 (1971). 
The nature of these complexities is such that the jurisprudence in the so-called "church-state" arena has been somewhat murky ${ }^{32}$ and has only become murkier in the past four decades ${ }^{33}$. The murkiness has been created by the difficulty of applying fairly complex judicial tests to what often are very fact-specific situations and the Court's increasing willingness to distinguish between a statute's facial constitutionality (unconstitutional by its very nature) and its constitutionality as applied ${ }^{34}$.

The United States Supreme Court's Establishment Clause jurisprudence has been dominated by a three-part test articulated in Lemon v. Kurtzman, the so-called "Lemon test":

Every analysis in this area must begin with consideration of the cumulative criteria developed by the Court over many years. Three such tests may be gleaned from our cases. First, the statute must have a secular legislative purpose; second, its principal or primary effect must be one that neither advances nor inhibits religion; finally, the statute must not foster "an excessive government entanglement with religion." ${ }^{35}$

In its later decisions the Court has tended to merge the last prong of the test, the "excessive entanglement" prong into the primary effect prong. As Madame Justice O'Connor wrote in her 1997 majority decision in Agostini v. Felton,

We have considered entanglement both in the course of assessing whether an aid program has an impermissible effect of advancing religion and as a factor separate and apart from "effect." Regardless of how we have characterized the issue, however, the factors we use to assess whether an entanglement is 'excessive' are similar to the factors we use to examine 'effect'...Thus, it is simplest to recognize why entanglement is significant and treat it-as we did in Walz-as an aspect of the inquiry into a statute's effects ${ }^{36}$.

If Agostini is the ruling decision, a two-prong test is administered. The first prong involves determining whether the statute being challenged has a legitimate secular purpose. In making this determination, the Court has tended to be very fact specific, carefully examining the legislative record and the expressed rationale for the law. This analysis extends far beyond a simple "rational basis" review. The Court does not base its findings on whether the law could have a legitimate secular purpose, but on whether the law as proposed and supported has as its main, if not overwhelmingly predominant, rationale some secular governmental purpose. If there is no legitimate secular purpose or the purpose of the statute was designed to further religion in some way, then a law is unconstitutional ${ }^{37}$. In instances where a government, in attempting to realize some legitimate secular purpose, provides

32 "Candor compels acknowledgment, moreover, that we can only dimly perceive the lines of demarcation in this extraordinarily sensitive area of constitutional law. The language of the Religion Clauses of the First Amendment is at best opaque, particularly when compared with other portions of the Amendment. Its authors did not simply prohibit the establishment of a state church or a state religion, an area history shows they regarded as very important and fraught with great dangers. Instead they commanded that there should be "no law respecting an establishment of religion." A law may be one "respecting" the forbidden objective while falling short of its total realization. A law "respecting" the proscribed result, that is, the establishment of religion, is not always easily identifiable as one violative of the Clause. A given law might not establish a state religion but nevertheless be one "respecting" that end in the sense of being a step that could lead to such establishment and hence offend the First Amendment. In the absence of precisely stated constitutional prohibitions, we must draw lines with reference to the three main evils against which the Establishment Clause was intended to afford protection: "sponsorship, financial support, and active involvement of the sovereign in religious activity." Lemon v. Kurtzman, 403 U.S. 602 (1971) at 612.

33 While on the one hand the Court appears to be inclined to allow certain activities that earlier Courts had deemed violative of the Establishment Clause, see for example the decision of Agostini v. Felton overruling Aguillar v. Felton, 473 U.S. 402 (1985). Despite this the Court does seem to be willing to allow the government greater authority to regulate the religious activities of individuals, the Smith case and religious organizations City of Boerne v. Flores as long as the regulations serve a legitimate governmental interest and are not specifically directed at religion or a particular religion. See Church of Lukumi Babalu Aye v. City of Hialeah, 508 U.S. 520 (1993).

34 See for example, Mitchell v. Helms, 530 U.S. 793 (2000).

35 Lemon v. Kurtzman, 403 U.S. 602 (1971) 612-613. Citations omitted.

36 Agostini v. Felton, 521 U.S. 203 (1997), at 232-33.

37 See for example, Edwards v. Aguillar, 482 U.S. 578 (1987). For a discussion of how this is applied in light of a free-exercise challenge see the decision in Church of Lukumi Bablu Aye v. City of Hialeah. 
funds to all organizations that adequately serve that purpose without regard to religion, however, "then it is fair to say that any aid going to a religious recipient only has the effect of furthering that secular purpose" 38 .

The nature of the organization receiving the funds and the structure of its beliefs seemingly have no bearing on determining whether the statute has a legitimate secular purpose. Additionally, the Court has stated that the fact that an organization receives governmental monies does not mean that the organization becomes part of the government. Merely receiving governmental monies does not turn an organization into a state actor for Constitutional purposes.

In distinguishing between indoctrination that is attributable to the State and indoctrination that is not, we have consistently turned to the principle of neutrality, upholding aid that is offered to a broad range of groups or persons without regard to their religion. If the religious, irreligious, and areligious are all alike eligible for governmental aid, no one would conclude that any indoctrination that any particular recipient conducts has been done at the behest of the government...If the government is offering assistance to recipients who provide, so to speak, a wide range of indoctrination, the government itself is not thought responsible for any particular indoctrination ${ }^{39}$.

While the potential implications of this statement will be discussed below, for now it is sufficient to recognize that the mere fact that a recipient of governmental funds to deliver a social service may also engage in religious teaching, by itself, does not necessarily implicate the Establishment Clause. If the government casts its net widely in providing funds to effect a legitimate, secular purpose, the sheer breadth of the net cast is sufficient to remove any taint of religious indoctrination by the government.

If the Court determines that the statute does have a legitimate, secular purpose, the Court moves to the next prong of the test. In this prong the Court seeks to determine whether the statute's primary or principal effect advances or inhibits religion. The Court makes such a determination by examining:

the character and purposes of the institutions that are benefitted, the nature of the aid that the State provides, and the resulting relationship between the government and the religious authority. Similarly we have assessed a law's effect by examining the character of the institutions benefitted (e.g., whether the religious institutions were 'predominantly religious') and the nature of the aid that the State provided (e.g., whether it was neutral and nonideological) ${ }^{40}$.

The Court looks to determine the extent to which the aid "is allocated on the basis of neutral secular, criteria that neither favor nor disfavor religion, and is made available to both religious and secular beneficiaries on a nondiscriminatory basis" ${ }^{\prime 1}$. In other words, the manner in which the funds find their way to a particular organization must be made on a basis completely separate from the religious character of the institution. Additionally, the program itself must not provide an incentive for the ultimate recipient of the services (in the case of Charitable Choice, the individual eligible for the services) to choose a religious provider over a secular provider. If an eligible individual would receive the particular services regardless of where she or he sought them then such an incentive does not appear to be created. An incentive to seek out religious indoctrination,

is not present, however, where the aid is allocated on the basis of neutral, secular criteria that neither favor nor disfavor religion, and is made available to both religious and secular beneficiaries on a nondiscriminatory basis. Under such circumstances, the aid is less likely to have the effect of advancing religion ${ }^{42}$.

\footnotetext{
Mitchell v. Helms, 530 U.S. 793 (2000) at 809.

Mitchell v. Helms, 530 U.S. 793 (2000) at 809.

Agostini at 232. Citations omitted.

Agostini at 231.

2 Agostini at 231
} 
A major component in determining whether neutrality has been met is whether funds flow to a religious organization "only as a result of the genuinely independent and private choices of individuals" ${ }^{\prime \prime 3}$. The Court views the aggregated private choices of individuals in choosing providers as a defense against governmental preference of one religion over another or of religious organizations over non-religious ones. Individual choice breaks the causal link between the government and the religious organization that may be the recipient of governmental monies. If the organization receives the money because of the choices of individuals it is wrong to impute any portion of the organization's religious content to the state. Even in those instances where the money flows directly to the institution in return for the delivery of a particular service, the Court, after its decision in Agostini and even more forcefully in its later decision Mitchell v. Helms (see below), is inclined to see the funds as reaching the organizations only "as a consequence of private decisionmaking" 44 .

In emphasizing the role of private choice, the Court in Mitchell seemingly rejects the previous distinctions it had made between direct and indirect aid ${ }^{45}$. Citing Agostini, the Court stated that, "[W]e have departed from the rule relied on in Ball that all government aid that directly assists [a religious organization] is invalid" ${ }^{\prime 4}$. By replacing the indirect/direct aid distinction with the categories of private choice and neutrality, the Court stated that it saw no difference between monies going directly to a religious organization as a result of private choices and neutral criteria and "the government issuing a paycheck to one of its employees knowing that the employee would direct the funds to a religious institution." ${ }^{\prime 7}$. In both instances, the Court declared, "Any money that ultimately went to religious institutions did so only as a result of genuinely independent and private choices of individuals" ${ }^{\prime 8}$.

Where an individual is entitled to receive a service and the provider is paid only to the extent it delivers the service to that individual, the recipient's act of choosing one provider (even if the provider is paid directly by the government) makes the funds flowing to the organization a matter of the eligible individual's choice. In such instances, the plurality in Mitchell stated that (for an educational context), "we see little difference in loaning science kits to students who then bring the kits to school, as opposed to loaning the science kits to the schools directly" 49 .

The Court takes a fairly functional approach to its understanding of private choice. Private choice is not only expressed when an individual who is directly given money or its equivalent chooses to purchase a service from a particular provider. For the Court, it is sufficient that an individual entitled to a particular service has a group of providers from which to choose, even if the money for that provision flows directly to the provider. If the provider is a religious organization, if it were chosen by a government to provide the services on bases unrelated to its religious character the establishment clause is not implicated.

If the statute itself meets the criteria laid out in both prongs of the Agostini test, the statute is facially valid. A court must then, if the facts of the case so dictate, look to see whether the statute as applied in a particular situation violates the second prong of the test $t^{50}$.

While the Supreme Court has not expressly stated what the distinction is between such analyses ${ }^{51}$, it has recognized such a distinction in numerous cases. In at least one case, the Supreme Court, while finding the challenged statute to be constitutionally valid "on its face" and "as applied" to the named

43 Agostini at 226.

44 Agostini, at 222. Mitchell, at 830.

45 This distinction between direct and indirect aid was expressly made in School Dist. of Grand Rapids v. Ball 473 U.S. 373 (1985).

46 Mitchell at 816 , citing to Agostini at 225.

47 Mitchell 817.

48 Mitchell 817

49 Mitchell at 831, citing to Walker at $1468, n .18$.

50 "There is, then, precedent in this area of constitutional law for distinguishing between the validity of the statute on its face and its validity in particular applications." Bowen v. Kendrick, 487 U.S. 589 (1988) at 602.

51 Bowen v. Kendrick, 487 U.S. 589 (1988) at 602. 
defendants, stated that, "[I]ndividual projects can be properly evaluated if and when challenges arise with respect to particular recipients and some evidence is then presented to show that the institution does in fact possess characteristics that make a grant of aid to the institution constitutionally impermissible" 52 .

The "as applied" analysis requires that a court first determine whether or not the statute is facially valid, that is constitutional as it is written. If the Court determines that the statute is not facially valid, then the analysis stops, and the statute is unconstitutional. If the statute, however, is found to be constitutional on its face, a court must then determine whether in the particular instance and in terms of the particular defendants the statute is being applied in a constitutional manner.

This latter component is of particular import, particularly for issues emerging from the application of the Charitable Choice Provision. For reasons discussed below, most of the provisions of the Charitable Choice Provision probably would meet all facial challenges. The possibilities for significant violations of the both the Establishment and Free Exercise Clauses in terms of how the various contractors deliver their services are great, however.

Not only do the contractors serve vulnerable populations who often fear the loss of their services, but also new faith-based contractors entering the governmental system often lack the sophistication necessary to distinguish between activities that are allowable and those that are not ${ }^{53}$. Additionally, political factors that encourage greater use of religious service providers may increase the possibilities of constitutional violations. Political considerations create at least the possibility for bias in favor of such providers and open the door for a lack of oversight and accountability ${ }^{54}$.

Such was the result in the first case to reach trial involving a contract to religious service provider involving Temporary Assistance to Needy Families (TANF) funds under the welfare reform bill. Although analyzed in detail below, the decision of the federal district court declared that the manner in which the funds were distributed and the use to which they were put violated the establishment clause. The court in Gaylor v. McCallum did not address the issue (and indeed the plaintiffs did not raise the question) of the constitutionality of the Charitable Choice Provision. This did not, however, prevent the judge from determining that where there is inadequate attention paid to the use of governmental funds and no "effective means of guaranteeing that the state aid derived from public funds will be used exclusively for secular, neutral, and nonideological purposes, it is clear...that direct aid in whatever form is invalid"55. Obviously whether there exist such effective guarantees will be case specific and can only be determined in the various applications of the statute to particular defendants.

52 Bowen, at 601, citing to Tilton v. Richardson, 403 U.S. 672 (1971) at 682.

53 In Indiana for example of the nine faith-based contractors in the initial year of the state's implementation of the Charitable Choice provision only one had previously held a contract from the state. Personal communication to the author.

54 This was one of the issues that emerged in the case the Freedom From Religion Foundation brought against the state of Wisconsin in Freedom From Religion Foundation, Inc. v. McCallum, 179 F. Supp. 2d 950 (W.D. Wis. 2002). In its decision the federal district court separated two different claims raised against the state of Wisconsin. In its initial decision the district court declared a state contract with an explicitly religious work readiness program, Faith Works, unconstitutional because the contract provided "unrestricted, direct funding of an organization that engages in religious indoctrination" at 954 (emphasis added) rather than indirect funding that followed and individual and was paid to Faith Works as a result of individual choice. It separated out the additional claim against the state's funding of Faith Works' drug and alcohol rehabilitation programming for prisoners because it needed further determination of the role of choice in the program. The district later rejected plaintiff's claim. On appeal, the federal appeals court rejected the Freedom from Religion Foundation's claim that such favoritism was built into the statute and declared nothing suggested otherwise. "There is no evidence that in recommending Faith Works a parole officer will be influenced by his own religious beliefs. His end is secular, the rehabilitation of a criminal, though the means include religion when the offender chooses Faith Works." The appeals court continued by emphasizing the role of choice in individuals' ability to select a service for which they are legally eligible." "Because the Supreme Court will not allow a public agency to force religion on people even if the agency honestly and indeed correctly believes that it is the best way of achieving a secular end that is within government's constitutional authority to promote, Lee v. Weisman, 505 U.S. 577, 587-89, 112 S. Ct. 2649, 120 L. Ed. 2d 467 (1992), the state may not require offenders to enroll in Faith Works even if it is the best halfway house in Milwaukee for any or even all offenders. Kerr $v$. Farrey, 95 F.3d 472, 479-80 (7th Cir. 1996). The choice must be private, to provide insulating material between government and religion. It is private; it is the offender's choice." Freedom from Religion Foundation, Inc., et al., Plaintiffs-appellants, v. Scott Mccallum, et al., Defendants-appellees, and Faith Works Milwaukee, Inc., Intervening Defendant-appellee, 324 F.3d 880 (7th Cir. 2003).

55 Nyquist, 413 U.S. at 780. 
While this case, Gaylor v. McCallum, expressly involved the question of a government contract with a religious provider, historically most of the cases decided by the Supreme Court that addressed the issue of governmental monies to religious organizations involved public schools. In fact, the United States Supreme Court has only heard two cases in its history dealing with governmental contracts with religious-based providers of social services, Bradfield v. Roberts, decided in 1899, and Bowen v. Kendrick, decided in 1988. The absence of such cases, given both the tremendous furor over governmental funding to religious schools and the immense amounts of funds that historically have flowed to faith-based providers of social and human services, remains somewhat surprising. While the explanation is not clear and one could attribute it to everything from the secularization of religious services, to strict governmental regulations, or to indifference, the fact remains that government contracting with faith-based providers of human and social services has engendered very little litigation of significance.

\subsection{Bradfield v. Roberts}

As discussed above, the case of Bradfield $v$. Roberts involved a contract let for the construction of an isolation wing in a hospital run by a Roman Catholic religious order and for reimbursement of the hospital for the costs (or a portion thereof) of its care for indigents. The hospital was located in Washington, D.C., and the contracting body was the United States Congress acting in its capacity as the District's legislative body.

Although charted as a private corporation, the hospital was wholly owned and controlled by the Sisters of Charity of Emmitsburg, Maryland. Its board of directors was comprised solely of members of the order and was self-perpetuating.

The Court described the case's history this way:

The plaintiff sued for an injunction barring the treasurer of the United States from paying the monies owed to the hospital under the contract. The plaintiff's contention being that the agreement if carried out would result in an appropriation by Congress of money to a religious society, thereby violating the constitutional provision which forbids Congress from passing any law respecting an establishment of religion ${ }^{56}$.

In its opinion the Court did not address the hospital's religious character. It simply looked at the hospital's articles of incorporation. The articles of incorporation simply showed the creation of a private corporation with appropriate rules and regulations that was designed to function as a hospital and which, as far as the record showed, did just that.

The Court expressly rejected the contention that the composition of its board, the nature of its governance, or its religious auspices could "change the legal character of the corporation or render it on that account a religious or sectarian body" ${ }^{\prime \prime 7}$. The Court continued, even assuming that the plaintiff's contentions regarding the hospital were true, they would not,

in the least change the legal character of the hospital, or make a religious corporation out of a purely secular one as constituted by the law of its being. [Namely the articles of incorporation.] Whether the individuals who compose the corporation under its charter happen to be all Roman Catholic, or all Methodists, or all Presbyterians, or Unitarians, or members of any other religious organization, or of no organization at all, is of no consequence with reference to the law of its incorporation, nor can the religious beliefs upon religious matters of the various incorporators be inquired into. Nor is it material that the hospital may be conducted under the auspices of the Roman Catholic Church...The meaning of the allegation is that the Church exercises great and perhaps controlling influence over

56 Bradfield v. Roberts at 295 .

57 Bradfield at 298. 
the management of the hospital. It must, however, be managed pursuant to the law of its being. That the influence of any particular church may be powerful over the members of a non-sectarian and secular corporation, incorporated for a certain defined purpose and with clearly stated powers, is surely not sufficient to convert such a corporation into a religious or sectarian body ${ }^{58}$.

Since the hospital as an incorporated entity was the creation of the State, and in this case the U.S. Congress, its existence and ultimate supervision and control were the sole responsibility "of the Government which created it"59.

The Court concluded its discussion of the hospital's nature by rejecting summarily that the hospital could be anything different from what its articles of incorporation made it to be and by emphasizing the inappropriateness of any review of the religious views of those who comprised the corporation. "In respect then of its creation, organization, management and ownership of property it is an ordinary private corporation whose rights are determinable by the law of the land, and the religious opinions of whose members are not subjects of inquiry"60.

The Court ended its opinion by stating that Congress had the authority to act in the manner it did. It was within its powers to appropriate funds for the purpose of aiding the indigent ill and to authorize the Commissioners of the District of Columbia "to enter into a contract with the trustees of an incorporated hospital for the purposes mentioned in the agreement..." 61

The Court in Bradfield took a formalistic approach to the question of (federal) government contracting with an organization that many could have viewed as religious in its nature. By starting with the assumption that the entity, the hospital, came into existence only through the articles of incorporation, the Court concluded that as an organization the hospital could only be what (and legally was only what) the articles made it. "All that can be said of the corporation itself is that it has been incorporated by an act of Congress, and for its legal powers and duties that act must be exclusively referred to." ${ }^{\prime \prime 2}$. Anything outside of the four-corners of the articles of incorporation was beyond the Court's purview. If the statute of incorporation were itself violated in any way, then Congress had the power to correct any such abuses. That issue, however was completely separable from whether Congress (acting though the Commissioners) could contract with this hospital.

One interesting element of the decision is that in two separate places the Court stated that an inquiry into the religious beliefs of those who comprised the corporation would be inappropriate. Although not elaborated, the statements are fairly emphatic and stand in direct contrast to many later decisions where the religious nature and make-up of the organization proved determinative to the outcome of the case. Interestingly, although often ignored, Bradfield remains good law and was cited approvingly by the Court in its other case involving governmental contracting with religious social service providers.

\subsection{Bowen v. Kendrick}

Despite the admonitions in Bradfield, the religious nature of the organization did play a role in the other United States Supreme Court decision looking at governmental contracting with religious organizations. This case, Bowen v. Kendrick 487 U.S. $589(1988)^{63}$, involved a challenge to the Adolescent Family Life Act (AFLA) 24 U.S.C. Sect. 300z et seq. Adopted by Congress in 1981, the statute was designed to address the problems seemingly created by pregnancy and childbirth among unmarried adolescents. AFLA authorized the Secretary of Health and Human Services to contract with public 
and nonprofit organizations to provide services and to undertake research in the areas of adolescent premarital sex and pregnancy. Among the specific areas targeted were the promotion of self-discipline and adoption of unwanted infants, the development of new means of delivering services to adolescents, as well as improving the means of communicating to adolescents the consequences of adolescent premarital sexual relations.

AFLA viewed the problem of adolescent premarital sexuality and its consequences as a serious and complex one, requiring the involvement of family, friends, and community organizations, including religious organizations as well as other charitable and voluntary associations ${ }^{64}$. It, therefore, required all applicants for funding to state how they would involve such organizations, including religious ones, in the provision of services ${ }^{65}$.

The statute also limited the services that could be provided by those eventually awarded contracts. Recipients could not provide family planning services unless there were no other providers of such services in the community (although they could make referrals) ${ }^{66}$. Organizations receiving funds under AFLA also were forbidden from providing abortion services or providing abortion counseling or referrals, except in response to a specific inquiry from the adolescent or her parents ${ }^{67}$.

In 1983 a suit was filed requesting declaratory and injunctive relief arguing that AFLA violated the Religion Clauses of the First Amendment both on its face and as applied. The District Court in a motion for summary judgment agreed with the plaintiffs, finding the statute invalid on its face and as applied "insofar as religious organizations are involved in carrying out the programs and purposes of the Act" ${ }^{\prime \prime 8}$.

On appeal, the Supreme Court in its decision held that the Act was constitutional on its face but remanded it to the District Court for a factual determination as to whether it was valid as applied. In determining whether AFLA ran afoul of the Establishment Clause, the Court used the unmodified Lemon Test ${ }^{69}$. The Court began by asking whether the statute served a legitimate secular purpose and determined that reducing adolescent sexual activity and out-of-wedlock pregnancies were legitimate secular goals. Additionally, the Court stated that Congress' considered decision that a multi-faceted approach using community-based resources, including religious organizations, would be more successful in dealing with the problems also was an appropriate secular purpose. The Court then proceeded to reject expressly the contention that "Congress' 'actual purpose' in passing AFLA was one of 'endorsing religion'"70.

That the purposes and goals of AFLA might coincide with the views and teachings of certain religious organizations did not bring AFLA into conflict with the Establishment Clause, a position the Court has held since at least $1890^{71}$. The Court concluded that it saw "no reason to conclude that AFLA served impermissible religious purposes simply because some of the goals of the statute coincide with the beliefs of certain religious organizations ${ }^{72}$. In so stating, the Court pointed to its decision in McGowan v. Maryland.

The "Establishment" Clause does not ban federal or state regulation of conduct whose reason or effect merely happens to coincide or harmonize with the tenets of some or all religions. In many instances, the Congress or state legislatures conclude that the general

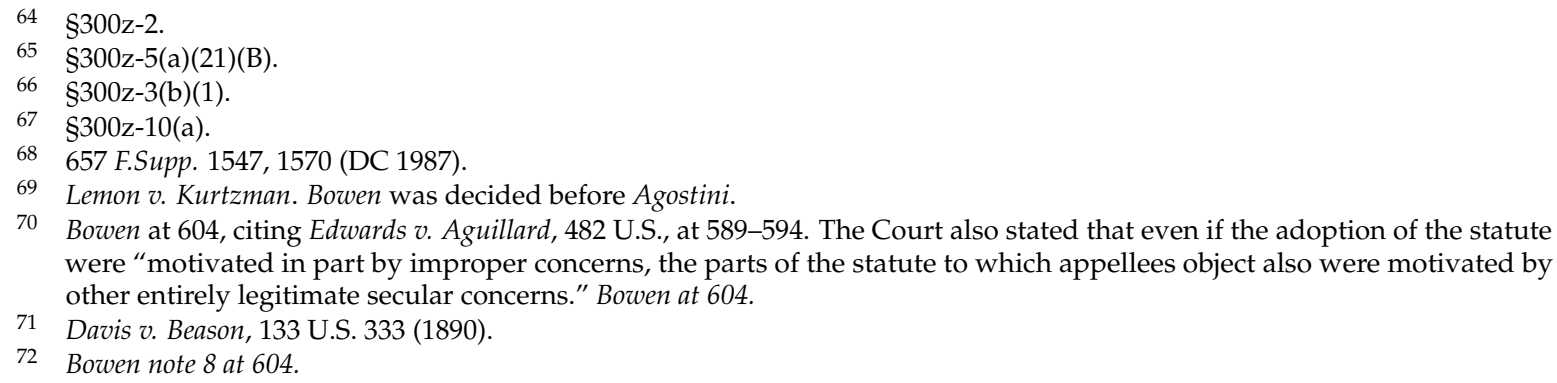


welfare of society, wholly apart from any religious considerations, demands such regulation. Thus, for temporal purposes, murder is illegal. And the fact that this agrees with the dictates of the Judaeo-Christian religions while it may disagree with others does not invalidate the regulation. So too with the questions of adultery and polygamy. The same could be said of theft, fraud, etc., because those offenses were also proscribed in the Decalogue ${ }^{73}$.

After a review of AFLA's statutory scheme, the Court concluded that there were two bases upon which one might conclude that AFLA were unconstitutional on its face. The first of these was that AFLA was unconstitutional because it expressly recognized "'that religious organizations have a role to play" in addressing the problems of teenage sexuality"74. Under this claim, even if no religious organizations received any funding, AFLA would be "invalid under the Establishment Clause because...it expressly enlists the involvement of religiously affiliated organizations in the federally subsidized programs, it endorses religious solutions to the problems addressed by the ACT, or it creates symbolic ties between church and state"75.

The Court dismissed this contention. Although AFLA mentions religious organizations in four places, speaking of the need for a variety of service providers to address the problem and requiring grantees to state how they will incorporate religious organizations into the services they will provide, the Court declared that, "these provisions of the statute reflect at most Congress' considered judgment that religious organizations can help solve the problem to which the AFLA is addressed"76.

The decision goes on to state that the Supreme Court has never said that Congress was prevented from "making such a judgment or from recognizing the important part that religion or religious organizations may play in resolving certain secular problems" ${ }^{\prime 77}$. Congress is free to make such determinations, especially in dealing with problems where the solutions involve family ties and family values. In such situations it is "sensible for Congress to recognize that religious organizations" have a role to play ${ }^{78}$. If such Congressional recognition has "any effect of advancing religion, the effect is at most 'incidental and remote ${ }^{\prime \prime 79}$.

Although AFLA requires grantees to discuss how they would integrate religious organizations into their service provision, this requirement has a broader context. It also requires grantees to discuss how they integrate numerous types of organizations, including "charitable organizations, voluntary associations, and other groups in the private sector" into this work ${ }^{80}$.

The broad reach established by this provision, the Court concluded, reflected its successful "maintenance of 'a course of neutrality among religions, and between religion and nonreligion."' 81 . This neutrality, neither favoring or disfavoring religion, meant that the requirement that religious providers be included was not an exception for religion, but merely a provision that maintained a balance between various organizations of all religious stripes and non-religious that might be able to aid the government in solving a serious secular problem.

The second basis the Court saw for challenging AFLA was that it allowed "religious institutions to participate as recipients of federal funds" ${ }^{\prime 82}$. In rejecting such an overarching challenge, the Court reviewed the history of its decisions (mostly involving religiously-affiliated private schools) where it had allowed religious institutions to receive such funds ${ }^{83}$. Additionally, the Court expressly noted that

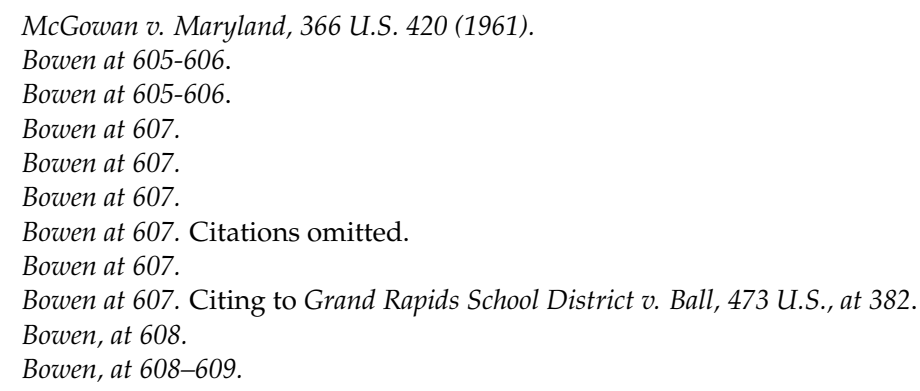


it had "never held that religious institutions are disabled by the First Amendment from participating in publicly sponsored social welfare programs" 84 . Citing Bradfield $v$. Roberts approvingly, the Court stated that, "the giving of federal aid to the hospital was entirely consistent with the Establishment Clause, and the fact that the hospital was religiously affiliated was 'wholly immaterial'" 85 . The Court in Bowen continued:

The propriety of this holding, and the long history of cooperation and interdependency between governments and charitable or religious organizations is reflected in the legislative history of the AFLA. (Charitable organizations with religious affiliations historically have provided social services with the support of their communities and without controversy $)^{86}$.

The one possible exception to this approval of providing funds to religious organizations to meet governmental purposes has involved monies flowing to "pervasively sectarian" organizations. The Court has understood pervasively sectarian organizations to be those in which religion is so predominant that it is impossible (or nearly so) to separate the religious component from any of the organization's undertakings ${ }^{87}$. The concern is that when an organization is pervasively sectarian, where religion consciously and intentionally pervades every element of the organization's activities, even governmental monies directed toward and used for "specific secular purposes, may nonetheless advance the pervasively sectarian institution's 'religious mission'" 88 .

The "pervasively sectarian" factor has traditionally dominated the Court's deliberations in cases related to governmental monies flowing to religiously affiliated schools. This has been true because historically religious schools not only reflect the teachings of particular traditions, but instruct in those teachings, and are dominated by members of the particular faith; they primarily exist to create a uniform religious environment that pervades the organization and everything that it does.

Unlike the Court's rejection of an inquiry into religious beliefs in Bradfield, the pervasively sectarian standard historically began with "a consideration of the nature of the institutions in which the [governmentally funded] programs operate" 89 . If the institutions in question are pervasively sectarian, the next step involves the determination whether and to what degree the challenged statute or program directs funds to those institutions.

Where the statute in question has (as was the case of AFLA) "facially neutral grant requirements" and a wide spectrum of potential grant recipients, including many religious ones which would not be considered pervasively sectarian, then, the decision stated, there is no basis for challenging the statute on its face. The mere possibility that "grants may go to religious institutions that can be considered 'pervasively sectarian'" is not "sufficient to conclude that no grants whatsoever can be given under the statute to religious organizations" 1 .

In such an instance, the Court will uphold the statute on its face and as applied to religious organizations that are not pervasively sectarian. It will, however, leave open the question of "the consequences that would ensue if they allowed federal aid to go to institutions that were in fact pervasively sectarian" ${ }^{\prime \prime 1}$. This means that in examining a statute as applied, the Court looks at the specific context, including a detailed analysis of the religious nature of the organization receiving the funds. This is a far cry from the formalistic standard of Bradfield.

In continuing to apply the "effects" prong of Lemon to AFLA, the Court also analyzed two elements particularly relevant to Charitable Choice. These are the role of religious organizations in

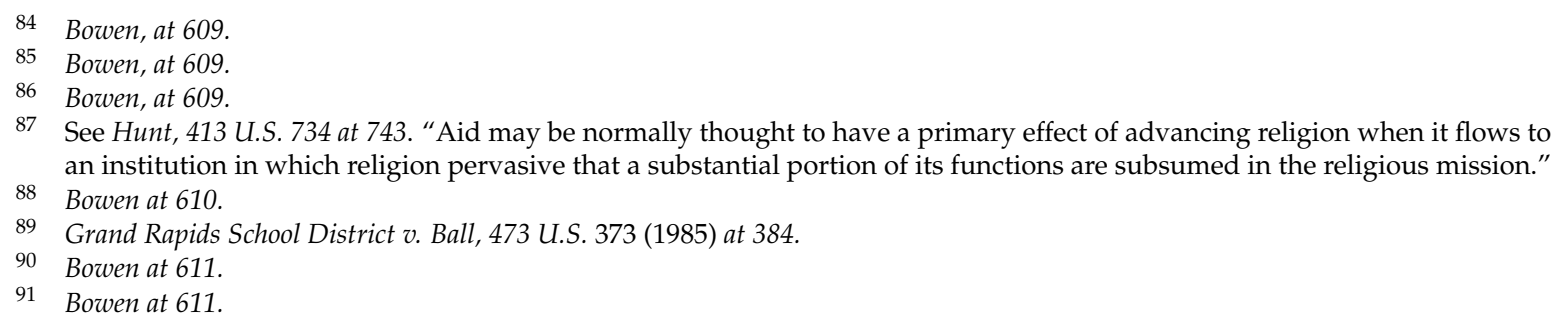


providing educational and counseling services and, more specifically, "teaching by religious grant recipients on matters fundamental to religious doctrine" ${ }^{\prime \prime 2}$.

In rejecting the claim that any funds that support teaching by religious organizations renders the statute unconstitutional, the Court began by declaring what was not allowable. Any situation resulting in "government financed or government-sponsored indoctrination into the beliefs of a particular religious faith" 193 or leading to "an unacceptable risk that government funding would be used to 'advance the religious mission' of the religious institution receiving aid"94 is prohibited by the Establishment Clause. The Court rejected the District Court's presumption that religious organizations would not follow their statutory and constitutional duties in delivering the services. The Court expressly stated just the opposite. "In contrast, when the aid is to flow to religiously affiliated institutions that were not pervasively sectarian, as in Roemer, we refused to presume that it would be used in a way that would have the primary effect of advancing religion" ${ }^{\prime \prime 5}$. The mere fact that under some circumstances there might be some inappropriate uses of the funds is an insufficient reason for the Court to declare a statute facially invalid ${ }^{96}$.

The Court also rejected the claim that AFLA's authorization of grantees to teach about matters that are central to many religious traditions rendered the statute unconstitutional. In matters of such importance as teenage sexuality, any policy decisions by Congress would coincide or conflict with some religious teachings. That fact, according to the Court, is insufficient to conclude that the act either advances or inhibits religion ${ }^{97}$. Even if the goals of AFLA were to coincide with the religious teachings of some of the grantees, this would not mean that the act crossed the line into funding religious activities "in an otherwise substantially secular setting" 98 .

AFLA, as the Court determined initially, served a legitimate secular purpose. The services it funded were designed to further that purpose. By definition, the Court concluded, such secular purposes are not "specifically religious activities," and neither are they "converted into such activities by the fact that they are carried out by organizations with religious affiliations" ${ }^{\prime \prime 9}$.

Finally, the Court rejected the argument that by involving and even funding religious organizations in the delivery of services, the statute created an impermissible "symbolic link" between government and religion. While acknowledging in passing the possibility that there may be occasions where such a link might be sufficiently strong to warrant striking a statute, this instance was not one of them. Somewhat derisively the Court dismissed this part of the District Court's decision highlighting the troubling reality such a doctrine would entail.

If we were to adopt the District Court's reasoning, it could be argued that any time a government aid program provides funding to religious organizations in an area in which the organization also has an interest, an impermissible "symbolic link" could be created, no matter whether the aid was to be used solely for secular purposes. This would jeopardize government aid to religiously affiliated hospitals, for example, on the ground that patients would perceive a "symbolic link" between the hospital-part of whose religious mission might be to save lives-and whatever government entity is subsidizing the purely secular medical services provided to the patient...[I]n this litigation, whatever "symbolic link"

92 Bowen at 612. Citations and internal quotation marks omitted.

93 Bowen at 611. Citing to Grand Rapids at 385.

94 Bowen at 611. Citing to Grand Rapids at 385. Citing to Meek at 370.

95 Bowen, at 612.

96 "It has not been the Court's practice, in considering facial challenges to statutes of this kind, to strike them down in anticipation that particular applications may result in the unconstitutional use of funds." Ibid. citing to Roemer at 761.

97 Bowen, at 613.

98 Bowen, at 613. Citing to Hunt, at 743.

99 Bowen, at 613. In this phrase one can catch again the Court's difference from Bradfield. In that the decision, the functional-religious nature and structure of the organization did not change its legal character. Here the religious nature of the organizations does not alter the character of the services. 
might in fact be created by the AFLA's disbursement of funds to religious institutions is not sufficient to justify striking down the statute on its face ${ }^{100}$.

Since AFLA had a legitimate secular purpose and, in its primary effect, neither advanced nor inhibited religion the Court concluded that the statute did not violate the Establishment Clause on its face $^{101}$. It then turned to the question of whether AFLA was valid as applied.

After chiding the District Court both for its approach to assessing whether the statute violated the Establishment Clause as applied and for its over-reaching remedy, the Supreme Court remanded the case for a hearing on whether the statute had been applied in an unconstitutional manner ${ }^{102}$. In doing so, the Court offered some guidelines for the District Court to follow in making that determination as well as in crafting a remedy for any violations.

The Supreme Court stated that the District Court must determine whether government monies had been:

provided to "pervasively sectarian" religious organizations

or

used to "fund specifically religious activities in an otherwise substantially secular setting"103.

If the District Court were to determine that a grant had been given to a pervasively sectarian institution or that funds had been used for explicitly religious activities, thereby running afoul of the Establishment Clause, or if any grantee had violated the strictures or rules promulgated to ensure compliance with the Constitution, the appropriate remedy would be to withdraw the grant from the particular grantee ${ }^{104}$. It is not an appropriate remedy to declare a statute unconstitutional under such circumstances ${ }^{105}$.

\section{The Constitutionality of the "Charitable Choice" Provision}

Bowen deserved such extensive analysis because the standards are the ones likely to be applied to all legal challenges to "Charitable Choice." Given the manner in which the provision was crafted and the purposes of the services funded by TANF monies, there is little likelihood that the statute overall would be found to be facially unconstitutional. One can draw this conclusion for the following reasons. The law serves a secular governmental purpose: the delivery of training to persons receiving TANF monies in order to prepare them for the workforce. As written, the provision simply appears to ensure

100 Bowen, at 613-614.

101 Bowen, at 617. Since this decision was written under the unmodified Lemon Test, the Court also examined the degree to which AFLA created an excessive entanglement. In just a few lines the Court rejected an entanglement claim. Since, as it had previously determined, most of the religious organizations receiving funds under AFLA would not be "pervasively sectarian" the amount of monitoring necessary to ensure compliance would be insufficient "to intrude unduly in the day-to-day operation of the religiously affiliated grantees." Bowen, at 616. Under the Agostini modification of the Lemon Test, this analysis would occur under the "primary effect" prong. There the result would have been the same.

102 Bowen, at 621.

103 Bowen, at 621 .

104 Bowen, at 621-22.

105 In an earlier part of the decision, the Court left open the possibility that statute might be so lacking in both express measures designed to ensure compliance with the Constitution and expressions of legislative intent that such compliance take place that it might be facially invalid. In fact, one could argue that a complete absence of such intent might mean the statute would fail the "secular purpose" prong of the Lemon test. The mere absence of "an express provision preventing the use of federal funds for religious purposes" is inadequate to reach that level, however. Bowen, at 614. While such a provision would be welcome and make it easier to conclude that a statute did not have the primary effect of advancing religion, it is not constitutionally required. Where, as in the case of AFLA, there is no intimation that religious uses are permitted and the legislative record itself suggested an absence of any religious intent, such facts are sufficiently adequate to conclude the statute neither had a goal other than a secular nor the goal of advancing religion. This conclusion can be buttressed by the regulations controlling the grant and the requirements placed on the grantees by the appropriate federal agencies. Ibid, at 614-15. 
that religious service providers are included in the universe of potential contractors for the delivery of those services. Religious providers are given no priority in the statute. The universe of the potential providers, both religious and non-religious, is huge. It therefore appears impossible for "pervasively sectarian" providers to dominate. Finally, the statute (unlike AFLA) contains provisions forbidding the use of funds for any express religious purposes.

If "Charitable Choice" overall seems to be valid on its face, there remains the problem of its application in specific circumstances and in the activities of certain religious or faith-based contractors. As mentioned above, the first legal challenge to contracts let under the provision to reach trial was solely as an applied challenge. The plaintiffs did not challenge the provision's constitutionality, only its application. The district court's analysis of this challenge deserves attention. It must await, however, an examination of one other issue-the plurality's decision in Mitchell $v$. Helms and a discussion of whether that decision has altered in major ways, the U.S. Supreme Court's Establishment Clause jurisprudence.

\section{The Strange Case of the Plurality Decision in Mitchell v. Helms ${ }^{106}$}

The plurality opinion written by Mr. Justice Thomas in Mitchell v. Helms presents some powerful challenges to an analysis of the current status of Establishment Clause jurisprudence. In many ways the decision clarifies and explains how to apply the modified Lemon Test as articulated in Agostini v. Felton. Additionally, by expressly declaring that the decisions rendered in Meek v. Pittenger ${ }^{107}$ and Wolman $v$. Walter ${ }^{108}$ to be no longer good law ${ }^{109}$, the Supreme Court removed what many had viewed as serious conflicts between those decisions and the Court's later decisions in Agostini and Zobrest v. Catalina Foothills School Dist ${ }^{110}$, as well as dicta (passing statements in a written decision with no precedential weight)—in Board of Ed. of Kiryas Joel Village School Dist. v. Grumet ${ }^{111}$.

Mitchell v. Helms involved a challenge to Chapter 2 of the Education Consolidation and Improvement Act of $1981^{112}$. The act provided federal funds to local agencies for programs assisting elementary and secondary school children. Among the activities allowed under Chapter 2 of the statute was the purchase "of instructional and educational materials, including library services and materials (including media materials), assessments, reference materials, computer hardware and software for instructional use, and other curricular materials"113.

These materials were to be provided to both public and nonprofit, private schools. The monies provided to any private schools were to be allocated on a basis equal to those allocated to public schools, on a per capita basis. The funds used for materials provided to private schools were to be allocated in such a way that they only supplemented the private schools' budgets and did not "supplant funds from non-Federal sources"114.

Numerous restrictions were placed on how the materials supplied to the private schools could be used. First, all the materials and equipment had to be "secular, neutral, and non-ideological"115. Additionally, the schools themselves never took title to the materials. They remained titled to the local education agency empowered to operate the program. The latter simply loaned the materials to the schools.

The district court found the program to be unconstitutional, in having a primary effect of advancing religion. It issued a permanent injunction barring the loan of equipment to pervasively

\footnotetext{
106 Mitchell v. Helms, 530 U.S. 793 (2000).

107 Meek v. Pittenger, 421 U.S. 349 (1975).

108 Wolman v. Walter, 433 U.S. 229 (1977).

109 Mitchell, at 808.

110 Zobrest v. Catalina Foothills School District, 509 U.S. 1 (1993).

111 Board of Ed. of Kiryas Joel Village School Dist. v. Grumet, 512 U.S. 687 (1994).

112 Education Consolidation and Improvement Act of 1981, 20 U.S.C. \$§7301-7373.

11320 U.S.C. $\$ 7351($ b $)(2)$.

$114 \S 7371(b)$.

$115 \S 7372(a)(1)$.
} 
sectarian schools. The Fifth Circuit upheld the ruling of the district court on the bases of Meek and Wolman, noting that while the Supreme Court's later decisions appeared to conflict with the former decisions the Supreme Court had not explicitly over-ruled either Meek or Wolman.

While commending the Fifth Circuit for its restraint, the Supreme Court proceeded to reverse the decision and in doing so expressly overruled Meek and Wolman. The Court based its decision on the modified Lemon Test as developed in Agostini. While the overall rationale for the Court's ruling is unimportant for this discussion, several elements in the plurality's decision are potentially of the utmost importance for future discussions of federal funding to religious organizations.

That said, the fact that the opinion of Mr. Justice Thomas commanded only a plurality of the Court ${ }^{116}$ and that the concurring opinion by Madame Justice $\mathrm{O}^{\prime}$ Connor ${ }^{117}$ disagreed in numerous places with the plurality's rationale raises questions about the applicability of the decision to future cases. With that caveat in mind, it is important to examine three elements of the decision. These are the plurality's rejection of the "pervasively sectarian" standard, the shift from examining whether the aid provided to religious organizations is direct or indirect to whether the funds flow as a result of individual choices, and, finally, the dismissal of the diversion of the aid as a constitutional problem.

The plurality opinion's express rejection of the "pervasively sectarian" standard undoubtedly has the potential for the most far-reaching impact. In a long line of cases, focusing primarily on private, religious schools, whether a recipient of governmental funds was pervasively sectarian could determine a case's outcome. Given the difficulty in the Court's view of preventing governmental support from being used to further the religious mission of pervasively sectarian institutions, the extent to which a program supplied funds to such institutions readily could be outcome determinative on both facial and as applied grounds. Indeed this was the basis for the Court's decision in both Meek and Wolman.

In rejecting the analytical category of pervasively sectarian organizations, the decision in Mitchell began by pointing to its decreasing role in the Court's decisions. By the time of the Court's decisions in Zobrest and Agostini, the decision argued, the determinative nature of this category of organizations had been diminished to nothing. Zobrest, the opinion pointed out, disregarded the fact that the funds went to a pervasively sectarian institution and focused instead on the importance of private choice and the absence of any government-funded religious content. In Agostini, according to the plurality, the majority decision "did not bother to mention that pervasively sectarian schools were at issue"118.

Beyond its declining significance in the Court's Establishment Clause jurisprudence, the plurality claimed that the "pervasively sectarian" factor should be dispensed for more substantive reasons as well. On a fundamental level, it is irrelevant. "The religious nature of a recipient should not matter to the constitutional analysis, so long as the recipient adequately furthers the government's secular purpose" $^{\prime 119}$. If the government offers "permissible aid" to all who can deliver a service adequately, "the religious (including the pervasively sectarian), the areligious, and the irreligious, it is a mystery which view of religion the government has established, and thus a mystery what the constitutional violation would be" ${ }^{\prime 20}$. Under such circumstances the pervasively sectarian institution has received no special benefit and by singling out those institutions for exclusion, the result is a "special hostility" reserved "for those who take their religion seriously, who think that their religion should affect the whole of their lives, or who make the mistake of being effective in transmitting their views to children"121.

Not only is it unnecessary to inquire into the depth and nature of a recipient's religious views, it is, the plurality declared, offensive. The Court pointed out that it has been well established in

\footnotetext{
116 The opinion written by Mr. Justice Thomas was joined by Mr. Chief Justice Rehnquist, and Messrs. Justices Scalia and Kennedy.

117 Madame Justice O'Connor was joined in her opinion by Mr. Justice Breyer.

118 Mitchell, at 827

119 Mitchell, at 827.

120 Mitchell, at 827.

121 Mitchell, at 827-28.
} 
"other contexts, that courts should refrain from trolling through a person's or institution's religious beliefs"122. Such trolling, however, is required to determine whether an institution is pervasively sectarian. Not only is this troubling on its own, but also it runs against the settled principle prohibiting "governments from discriminating in the distribution of public benefits based on religious status or sincerity"123. The government, including the courts, cannot prevent an institution, otherwise qualified, from participating in a widely available program simply because it or its members hold their religious beliefs strongly and fervently. Religion is not to be disfavored.

Finally, the Court claims that the hostility to aiding pervasively sectarian institutions "has a shameful pedigree that we do not hesitate to disavow"124. Born amidst the anti-Catholic bias of the late nineteenth century as reflected in the history of the so,-called "Blaine amendments," it was an open secret that "sectarian" was a code for "Catholic"125.

Although "sectarian" could be used for organizations established by any religious body, the Court, according to the plurality, eliminated this potential use by adopting the phrase, "pervasively sectarian." This term, according to Mr. Justice Thomas, "could be applied almost exclusively to Catholic parochial schools and which even today's dissent exemplifies chiefly by reference to such schools"126.

In concluding its discussion of the pervasively sectarian category of institutions, the opinion states that the Establishment Clause does not require the exclusion of pervasively sectarian institutions from otherwise constitutional aid programs. Additionally, other Constitutional principles forbid such exclusions. For these compelling reasons, the opinion declares, "This doctrine [no funds to pervasively sectarian institutions], born of bigotry, should be buried now"127.

If Mitchell signaled the end of the pervasively sectarian factor, it also may have reflected, a major shift in the Court's Establishment Clause jurisprudence, signifying a turn to a pure neutrality standard that gives no consideration to the nature of the institution receiving governmental monies ${ }^{128}$. Despite Mr. Justice Thomas's suggestion that the end of the pervasively sectarian standard is nothing more than a return to the positions adopted in Everson v. Board of Education and Board of Education v. Allen ${ }^{129}$ and, one might add, Bradfield as well, the rejection of the pervasively sectarian standard eliminates what many understood to be a settled legal principle.

If Mitchell signified an end to the "pervasively sectarian" factor as part of Establishment Clause jurisprudence, its rejection of the "no divertability" rule potentially constricts greatly both the number and kinds of challenges that could be brought against programs that provide governmental funds to religious institutions.

For the Court, the ability of an organization to use support-whether funds, equipment, or training-for religious purposes does not reach the Constitution. "The evidence of actual diversion and the weakness of the safeguards against actual diversion are not relevant to the constitutional inquiry, whatever relevance they may have under the statute and regulations"130.

In rejecting the "no divertability" rule the decision expressly stated that where the aid provided by the government is religious in nature it is impermissible under the Constitution. It continues, however, arguing that where the "aid is not itself unsuitable...because of religious content, and eligibility for aid

\footnotetext{
122 Mitchell, at 827-28.

123 Mitchell, at 827-28.

124 Mitchell, at 827-28. While the Court's decision in this case speaks directly to aid to schools given the fact that historically aid to schools has had to meet a higher standard than aid to other institutions, the argument should hold across the board.

125 Mitchell, at 827-28.

126 Mitchell, at 829.

127 Mitchell, at 829 .

128 For a favorable discussion of the neutrality standard see [29]. For a critique see [30].

129 Board of Education v. Allen 392 U.S. 236.

130 Mitchell, at 834 .
} 
is determined in a constitutionally permissible manner, any use of that aid to indoctrinate cannot be attributed to the government and is thus not of constitutional concern"131.

Finally, Mitchell (as discussed earlier), signifies an express shift from the Court's use of direct versus indirect aid as a touchstone for the constitutionality of programs that fund religious organizations. Dismissing as irrelevant formalisms the distinction between monies or materials provided to individuals who then give them to religious institutions and those given directly to the institutions on behalf of the individuals ${ }^{132}$, the Court went on to conclude that "private choice and neutrality resolve the concerns formerly addressed by the [indirect/direct aid] rule"133.

Following Mitchell, there seems to be little left of traditional Establishment Clause jurisprudence except for two elements. Government cannot directly expend funds for programs with religious content and government funds cannot intentionally be designed to further (or hinder) religious ends. Additionally, while the misallocation of the monies for religious purposes can lead to sanctions, there mere fact that the monies can be diverted to such purposes does not in and of itself render a statute unconstitutional.

\section{Conclusions}

This article sought to provide the relevant historical and legal background necessary to any informed and reasonable discussion of government contracting with faith-based organizations. The inclusion of the "Charitable Choice" provision in the 1996 welfare reform bill brought to the fore an issue that many had ignored, namely the fact of such contracting, its magnitude, and its long history. The ignorance of that history led many to view "Charitable Choice" as a novelty. While it may have been, its novelty lay not in in opening up faith-based organizations to government contracting but mostly in requiring states to allow them to participate equally.

A more important question involved the constitutionality of such contracts. What if anything were the limits?

A complicating element in the discussion was that "Charitable Choice" was adopted during a fairly unsettled time in establishment clause jurisprudence. Seemingly settled issues were being undone and clarity was lacking.

When combined with the aggressiveness of the proponents of faith-based social services, many feared that we were facing a monster of governmentally funded religious indoctrination and coercion. The monster, however, seems to be relatively meek. Despite the shifting nature of establishment clause jurisprudence, several elements seem solid. Governments may not directly fund any services that have an explicit religious content. When a government identifies a wide variety of providers from which an individual entitled to that service may choose, the fact that a particular provider may have an express religious component is irrelevant. The individual's choice is essential. In such instances the government may pay the provider directly. Finally, the government cannot act in a manner that coerces or forces an individual to use a provider with express religious content.

The biggest change seems to be that constitutional determinations now focus overwhelmingly on the element of individual choice in selecting a service and determining that the choice is real. The nature of the organization, whether or not it is "pervasively sectarian" has become irrelevant. What an organization does, not what it is, matters, along with the individual's freedom to choose what it does (and how).

131 Mitchell, at 821. This does not mean that there would be no consequences for doing so. As the Court stated in the appropriate response would be revocation of the contract. Just as fraud or misappropriation of a military contract can be corrected through non-constitutional means, so can a contract with a faith-based service provider. The mere fact that such a provider illegitimately may use the funds to promote religion is no more imputable to the government than is the theft or misappropriation of monies is imputable to the government in a military contract.

132 Mitchell, at 817.

133 Mitchell, at 816 . 
While fears about the consequences of "Charitable Choice" and its offspring seem to have been unfounded, there has been a substantial positive result in the field of scholarship. Many have been led to a greater attention to the role that faith-based organizations play in the delivery of services, their place in the ecology of government contracting, and, more broadly, the role of religion and religious belief in civil society. Such explorations were overdue.

Conflicts of Interest: The authors declare no conflict of interest.

\section{References and Notes}

1. "Executive Order 13199-Establishment of White House Office of Faith-Based and Community Initiatives." Available online: http:/ /www.presidency.ucsb.edu/ws/?pid=61481 (accessed on 21 March 2016).

2. Carl Esbeck (at that time Director, Center for Law \& Religious Freedom (CLRF) Springfield, Virginia). Personal communication, 16 May 2001.

3. The web site of the White House of Faith-Based and Community Initiatives. Available online: http://www.ed.gov/offices/OIIA/pfie/whoweare/faithbased.html (accessed on 20 March 2002). This site currently is removed and there does not seem to be an archived version available.

4. Sheila Suess Kennedy, and Wofgang Bielfeld. Charitable Choice at Work: Evaluating Faith-Based Job Programs in the States. Washington: Georgetown University Press, 2006.

5. Leonard W. Levy. The Establishment Clause: Religion and the First Amendment. New York: Macmillan, 1986.

6. Kent Greenawalt. Religion and the Constitution: Vol. 2. Establishment and Fairness. Princeton: Princeton University Press, 2008.

7. Wolfgang Bielefeld, and William Suhs Cleveland. “Defining Faith-Based Organizations and Understanding Them through Research." Nonprofit and Voluntary Sector Quarterly 42 (2013): 442-67. [CrossRef]

8. Steven Rathgeb Smith, and Michael Lipsky. Non Profits for Hire: The Welfare State in the Age of Contracting. Cambridge: Harvard University Press, 1993.

9. Martha Minow. "Partners, Not Rivals: Redrawing the Lines between Public and Private, Non-Profit and Profit, and Secular and Religious." Boston University Law Review 80 (2000): 1061-94.

10. Lester M. Salamon. "Partners in Public Service: The Scope and Theory of Government Nonprofit Relations." In The Nonprofit Sector: A Research Handbook. Edited by Walter W. Powell. New Haven: Yale University Press, 1987, p. 100.

11. Lester M. Salamon, and Lester M. Salamon. Partners in Public Service: Government Nonprofit Relations in the Modern Welfare State. Baltimore: Johns Hopkins University Press, 1995.

12. John S. Whitehead. The Separation of College and State: Columbia, Dartmouth, Harvard, and Yale, 1776-1876. New Haven: Yale University Press, 1973.

13. Marvin Olasky. The Tragedy of American Compassion. Washington: Regnery Gateway, 1992, p. 14.

14. Ralph Kramer. Voluntary Agencies in the Welfare State. Berkeley: University of California Press, 1981, p. 61.

15. Frank Fetter. "The Subsidizing of Private Charities." American Journal of Sociology 7 (1901-1902): 359-85. [CrossRef]

16. Robert Bremner. The Public Good: Philanthropy and Welfare in the Civil War Era. New York: Alfred A. Knopf, 1980, p. 87.

17. Diane Winston. Red-Hot and Righteous: The Urban Religion of the Salvation Army. Cambridge: Harvard University Press, 1999, pp. 136-37 and passim.

18. Amos Warner. American Charities. New York: Thomas Y. Crowell, 1908, pp. 409, 413.

19. Bernard J. Coughlin. Church and State in Social Welfare. New York: Columbia University Press, 1965, p. 46.

20. J. Bruce Nichols. The Uneasy Alliance: Religion, Refugee Work, and U.S. Foreign Policy. New York: Oxford University Press, 1988.

21. R. Pierce Beaver. Church and State, and the American Indians. St. Louis: Concordia, 1966.

22. Charles C. Coffin. The Boys of '61 or, Four Years of Fighting. Boston: Estes and Lauriat, 1880, p. 373.

23. Edward L. Queen, II. In the South the Baptists Are the Center of Gravity: Southern Baptists and Social Change, 1930-1980. Lehi: Carlson Publishing, 1991, p. 106ff.

24. Lester Salamon. "The Marketization of Welfare: Changing Nonprofit and For-profit Roles in the American Welfare State." Social Service Review 67 (1993): 16-39. [CrossRef] 
25. John McCarthy, and Kim Castelli. Religion-Sponsored Social Service Providers: The Not-So-Independent Sector. Working Paper Series. Washington: The Aspen Institute, 1998.

26. “Forbes Magazine's 2015 list of the 50 largest U.S." Available online: http://www.forbes.com/top-charities/ list/\#tab:rank (accessed on 14 March 2016).

27. Stephen Monsma. When Sacred and Secular Mix: Religious Nonprofit Organizations and Public Money. Lanham: Rowman \& Littlefield, 1996, p. 68.

28. Kenneth Craycraft. The American Myth of Religious Freedom. Dallas: Spence Publishers, 1999.

29. Carl A. Esbeck. "A Constitutional Case for Governmental Cooperation with Faith-Based Social Service Providers." Emory Law Journal 46 (1997): Article 1.

30. Alan E. Brownstein. "Interpreting the Religion Clauses in Terms of Liberty, Equality, and Free Speech Values-A Critical Analysis of 'Neutrality Theory' and Charitable Choice." Notre Dame Journal of Law Ethics E Public Policy 13 (1999): Article 243.

(C) 2017 by the author; licensee MDPI, Basel, Switzerland. This article is an open access article distributed under the terms and conditions of the Creative Commons Attribution (CC BY) license (http:/ / creativecommons.org/licenses/by/4.0/). 